\title{
Vincosamide inhibits malignant behaviors of hepatocellular carcinoma cells by activating caspase- 3 activity and blocking the PI3K/AKT signaling pathway
}

\section{Mingyue Zhu}

Hainan Medical University

Haipeng Feng

Hainan Medical University

Bo Lin

Hainan Medical University

Ying Zhou

Hainan Medical University

Yifeng Zheng

Hainan Medical University

Kun Liu

Hainan Medical University

Mengsen Li ( $\square$ mengsenli@163.com )

Hainan Medical College

\section{Research}

Keywords: Vincosamide inhibits HCC cells malignant behaviors

Posted Date: May 15th, 2020

DOI: https://doi.org/10.21203/rs.3.rs-28543/v1

License: (c) (i) This work is licensed under a Creative Commons Attribution 4.0 International License. Read Full License 


\section{Abstract \\ Background}

Vincosamide(Vinco) was first identified in the methanolic extract of the leaves of Psychotria leiocarpa, and Vinco has important anti-inflammatory effects and activity against cholinesterase. However, whether Vinco inhibits the malignant behaviors of hepatocellular carcinoma(HCC) cells is still unclear. In the present study, we explored the role of Vinco in suppressing the malignant behaviors of HCC cells.

\section{Methods}

MTT and trypan blue exclusion assays were applied to detect the proliferation and death of HCC cells; electron microscopy was performed to observe change in cellular mitochondrial morphology; scratch repair and Transwell assays were used to analyze the migration and invasion of HCC cells; the expression and localization of proteins were detected by laser confocal microscopy and Western blotting; and the growth of the cancer cells in vivo was assessed in a mouse tumor model.

\section{Results}

At a dose of $10-80 \mu \mathrm{g} / \mathrm{ml}$, Vinco inhibited the proliferation of HCC cells and promoted their apoptosis in a time- and dose-independent manner but had little effect on normal liver cells. Additionally, $80 \mu \mathrm{g} / \mathrm{ml}$ Vinco significantly disrupted the morphology of mitochondria and suppressed the migration and invasion of HCC cells. The growth of HCC cells in the animal tumor model was significantly inhibited after treatment with Vinco $(10 \mathrm{mg} / \mathrm{kg} /$ day) for 3 days. The results of the present study indicate that Vinco (10$80 \mu \mathrm{g} / \mathrm{ml}$ ) plays novel roles in activating caspase-3, promoting the expression of PTEN, and inhibiting the phosphorylation of AKT(Ser 473) and mTOR (Thr2448) and that Vinco was able to also suppress the expression of CXCR4, Src, MMP9, EpCAM, Ras and Oct4 in HCC cells.

\section{Conclusions}

Vinco plays a role in inhibiting the malignant behaviors of HCC cells, and the molecular mechanism may involve in suppressing the expression of the growth-, metastasis-related factors Src, Ras, MMP9, EpCAM and CXCR4 and activating the activity of caspase-3. Vinco also blocks the PI3K/AKT signaling pathway. Thus, Vinco is an available chemotherapy for HCC patients.

\section{Introduction}

The genus Psychotria (Rubiaceae) contains more than 2000 species that mostly grow in tropical and subtropical regions[1]. Vincosamide (Vinco) was first identified in the methanolic extract of the leaves of Psychotria leiocarpa. Palicourea species (including Psychotria leiocarpa) have been used in folk medicine 
for the treatment of some disorders, including inflammatory disorders and cancer[2-4]. Some evidence indicates that Vinco was able to inhibit the growth of glioma cell lines[2], protect against inflammatory diseases and respiratory disturbances, and exert anti-hallucinogenic effects[5]. Monoterpene indolic alkaloid(N- $\beta$-glucopyranosyl vincosamide) is the main component of extracts from the leaves of Palicourea species collected from Morro Santana in Porto Alegre, Brazil[6]. It has been reported that Vinco has pharmacological effects, such as anti-oxidant effects and anti-mycobacterial effects against the growth of Mycobacterium bovis[7], and analgesic activity[8]. Additionally, it exhibits anti-inflammatory effects and dose-independent analgesic activity, and its effects are not reversible by naloxone. Vinco also plays a role in protecting against doxorubicin-induced cardiotoxicity[9]. These findings suggest that Vinco not only has anti-inflammatory and anti-oxidant effects and inhibits the growth of cancer cells, but also has little cytotoxicity in normal cells. Although Vinco has been reported to have anti-inflammatory and anti-oxidant activities, inhibit the growth of cancer cells, and protect normal cells; the effect of Vinco on hepatocellular carcinoma ( $\mathrm{HCC}$ ) cells is still unclear, and the target of Vinco in suppressing the malignant behaviors of cancer cells has not been determined.

Considering that species of the genus Psychotria have been used as anti-inflammatory agents, antimicrobial drugs and cancer treatments despite a lack of scientific evidence of their potential therapeutic applications, research on the therapeutic potential of Vinco was performed in this study. The goal of this study was to explore the effect of Vinco on the malignant behaviors of HCC cells in vitro and its anticancer role in a mouse model in vivo.

\section{Material And Methods}

\section{Cell culture}

The human normal liver cell line L-02 and the human HCC cell lines HLE, Bel 7402 and PLC/PRF/5 were selected for the present study. These cells were gifts from the Department of Cell Biology and Department of Biochemistry and Molecular Biology, Peking University Health Science Centre (Beijing, China). The cells were cultured in RPMI 1640 medium supplemented with 10\% heat inactivated fetal calf serum (FCS) and were incubated at $37{ }^{\circ} \mathrm{C}$ in a humidified atmosphere containing $5 \% \mathrm{CO}_{2}$ as previously described $[10,11]$.

\section{MTT assay}

L-02, HLE, Bel 7402 and PLC/PRF/5 cells were digested with trypsin and diluted in RPMI 1640 medium containing $10 \%$ FCS to form a suspension of $2.5 \times 10^{4}$ cells $/ \mathrm{ml}$, and $200 \mu \mathrm{l} /$ well was subcultured in 96 well plates. After incubation for $48 \mathrm{~h}$ in the plates, the cells were treated with different concentrations of Vinco $(5,10,20,40$, or $80 \mu \mathrm{g} / \mathrm{ml}$ ) (purchased from Chengdu Greenpurify Biology Medicine Company, Chengdu, China) for 48 h. Then, 3-(4,5-dimethylthiazol-2-yl)-2, 5-diphenyl- tetrazolium bromide (MTT) solution $(5 \mathrm{mg} / \mathrm{ml})$ was added to each the cells in each well, and the cells were cultured for another $4 \mathrm{~h}$. The culture medium containing MTT was discarded, and $200 \mu \mathrm{L}$ of dimethylsulfoxide was added to each well. The plates were oscillated for $10 \mathrm{~min}$. The absorbance values of the experimental group were 
measured by a microplate reader (Bio-Rad) at a wavelength of $490 \mathrm{~nm}$. The growth ratio was calculated by the following formula: growth ratio=(treated $A_{490}(\mathrm{~nm}) /$ control $\left.A_{490}(\mathrm{~nm})\right) \times 100 \%$. The procedure and calculations were based on a previous description[10]. The follow figure indicate the molecular structure of Vinco.

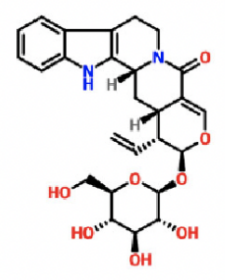

Molecular structure of Vinco; element components: C26H30N2O8; molecular weight: 498.532 Da.

\section{Microscopy and DAPI nuclear staining to observe cell morphology}

To observe alterations in cellular morphology induced by Vinco, L-02, HLE, Bel 7402 and PLC/PRF/5 cells were plated at a density of $2.0 \times 10^{4} / \mathrm{ml}$ in 24-well plates. The cells were cultured in RPMI 1640 medium supplemented with $10 \% \mathrm{FCS}$ at $37^{\circ} \mathrm{C}$ in a humidified atmosphere of $5 \% \mathrm{CO}_{2}$ for $48 \mathrm{~h}$, and then treated with $10 \mu \mathrm{g} / \mathrm{ml}$ or $80 \mu \mathrm{g} / \mathrm{ml}$ Vinco. After treatment for $48 \mathrm{~h}$, cellular morphology was observed under a light microscope, and the cells were stained with 4,6-diamidino-2-phenylindole dihydrochloride (DAPI) solution. The cells were imaged using a fluorescence microscope at 100x magnification. In this study, nuclear pyknosis and fragmentation were used as evidence of apoptosis, and these criteria were evaluated by fluorescence microscopy as previously described[12,13].

\section{Trypan blue exclusion dye method to analyze cell viability and metabolic activity}

To evaluate cell viability, L-02, HLE, Bel 7402 and PLC/PRF/ 5 cells were seeded at a density of $2.5 \times 10^{4}$ cells per well in 6-well plates, and the cells were cultured in RPMI 1640 medium supplemented with 10\% FCS at $37^{\circ} \mathrm{C}$ in a humidified atmosphere of $5 \% \mathrm{CO}_{2}$ for $48 \mathrm{~h}$. Following treatment with different concentrations of Vinco $(10 \mathrm{mg} / \mathrm{ml}$ or $80 \mathrm{mg} / \mathrm{ml})$ for $48 \mathrm{~h}$, cell viability was determined by the trypan blue exclusion dye assay using a Trypan Blue Staining Cell Viability Assay Kit (Beyotime Biotech Corp, Haimen, Jiangshu, China). Cells that restricted trypan blue entry were considered viable. The cell viability ratio was calculated according to the following formula: (control group viable cells-treated groups viable cells)/control group viable cells $\times 100 \%$. The death of cells was evaluated by microscopy as previously described[14]

\section{Electron microscopy to observe mitochondria}

HLE, Bel 7402 and PLC/PRF/ 5 cells were cultured in RPMI 1640 medium supplemented with $10 \%$ FCS at $37^{\circ} \mathrm{C}$ in a humidified atmosphere of $5 \% \mathrm{CO}_{2}$. The cells were treated with Vinco $(80 \mu \mathrm{g} / \mathrm{ml})$ for $48 \mathrm{~h}$ and then harvested, washed with phosphate-buffered saline (PBS) two times $\left(4^{\circ} \mathrm{C}, 10 \mathrm{ml}, 8 \mathrm{~min}\right)$, and transferred to $1.5-\mathrm{ml}$ EP tubes. The cells were fixed, and ultrathin sections $(0.1 \mu \mathrm{M})$ were prepared. The 
ultrathin sections were examined under a TECNA 10 transmission electron microscope (Philips, Holland). The morphological characteristics of cellular mitochondria were observed by randomly selecting ten cells from each group. Mitochondrial damage was evaluated by electron microscopy as previously described[15].

\section{Cellular wound repair assay}

Cell motility was analyzed by a wound repair assay. HLE, Bel 7402 and PLC/PRF $/ 5$ cells $\left(5 \times 10^{4} \mathrm{cells} / \mathrm{ml}\right)$ were seeded in 12-well plates and allowed to reach almost total confluence in $24 \mathrm{~h}$. A scratch was made by scraping the middle of the cell monolayer with a sterile micropipette tip. The cells were cultured with RPMI 1640 medium containing $10 \%$ FCS and Vinco $(10 \mu \mathrm{g} / \mathrm{ml})$. Then, images of the cells that migrated into the wound area were captured at 0,24 , and $48 \mathrm{~h}$ by an inverted microscope (100x), and their distances traveled were recorded. Cell repair motility was evaluated using the following formula: cell repair ratio $(\%)=($ distance at $0 \mathrm{~h}$-distance at $\mathrm{X} h) /$ distance at $\mathrm{O} \mathrm{h} \times 100 \%$, with $\mathrm{X}$ representing the time points of observation. The procedure was performed as previously described[16].

\section{Cell invasion assay}

The cell invasion assay was carried out on HLE, Bel 7402 and PLC/PRF/5 cells according to the manufacturer's protocols. Cell invasion was measured by observing cells cultured on inserts in Transwell chambers (Transwell chamber; 8-mm pore size; Costar, High Wycombe, UK) covered with Matrigel (BD Falcon, NJ, USA). The cells were plated in 12-well culture plates with separate upper and lower chambers. The cells were added to the upper chambers $\left(5 \times 10^{4}\right.$ cells $\left./ \mathrm{ml}\right)$, cultured with serum-free RPMI 1640 medium and treated with Vinco $(10 \mu \mathrm{g} / \mathrm{ml}$ and $80 \mu \mathrm{g} / \mathrm{ml})$, whereas the lower chamber was filled with complete medium (containing $20 \%$ FCS). After $48 \mathrm{~h}$ of incubation, the cells in the upper chamber were carefully removed with a cotton swab, and those that had invaded through the membrane to the lower surface were fixed with $90 \%$ methanol and stained with $0.1 \%$ crystal violet. The number of cells that had invaded through the membrane was quantified by counting the cells in five different visual fields under a microscope (Olympus) with a $20 \times$ objective. Three independent assays were performed.

\section{Laser confocal microscopy}

HLE, Bel 7402 and PLC/PRF/5 cells were stained as described previously[14]. To observe the migration of caspase-3 molecules, cells were treated with Vinco $(10 \mu \mathrm{g} / \mathrm{ml}$ and $80 \mu \mathrm{g} / \mathrm{ml})$; to evaluate the expression and location of Src, Oct4 and PTEN, cells were treated with Vinco $(80 \mu \mathrm{g} / \mathrm{ml})$. Laser confocal microscopy was performed to observe the expression and location of the target proteins. Briefly, cells were fixed in $4 \%$ paraformaldehyde and incubated with mouse anti-human caspase-3 and anti-Src antibodies and rabbit anti-human Oct4 and anti-PTEN antibodies (Abcam Trading (Shanghai) Company, Ltd., Shanghai, China) for 24 h. Alex 488-, Alex 647-, or fluorescein isothiocyanate (FITC)-conjugated secondary anti-mouse immunoglobulin $\mathrm{G}(\mathrm{IgG})$ was added, and the cells were incubated for $2 \mathrm{~h}$. Afterwards, $100 \mu \mathrm{l}$ of DAPI (1 $\mu \mathrm{g} / \mathrm{ml}$ ) was added for $30 \mathrm{~min}$. The cells were visualized with a Leica TCS-NT SP2 laser confocal microscope (Leica Camera, Wetzlar, Germany). 


\section{Western blotting analysis}

To estimate the influence of Vinco on the expression of proteins related to metastasis and apoptosis, and the PI3K/AKT signaling pathway, HLE, Bel 7402 and PLC/PRF/ 5 cells were treated with Vinco $(10 \mu \mathrm{g} / \mathrm{ml}$ or $80 \mu \mathrm{g} / \mathrm{ml}$ ) for $24 \mathrm{~h}$. The expression of metastasis-related proteins, such as MMP9, CXCR4, and EpCAM; apoptosis-related proteins, such as activated caspase-3, PARP-1, PTEN, Bax, and Bcl-2; and factors regulated by the PI3K/AKT signaling pathway, such as pAKT (Ser473), and pmTOR (Thr2448), in these cells was analyzed by Western blotting as previously described[16].

\section{Immunohistochemical analysis}

The protein expression of C-myc, Ras, activated caspase-3 and PARP-1 in tumor-bearing mice was evaluated by immunohistochemical analysis. Briefly, tumorous tissue was removed from tumor-bearing mice and cut into five-millimeter-thick paraffin sections. The sections were deparaffinized and rehydrated according to standard protocols. The sections were then incubated with primary antibody (1:100 dilution; Abcam Trading (Shanghai) Company, Ltd., Shanghai, China) at $4{ }^{\circ} \mathrm{C}$ overnight. Nonimmune (IgG) was used as a negative control, and antigenic sites were identified using an SP9000 Polymer Detection System and a 3,3'-diaminobenzidine kit (ZSGB-BIO, Beijing, China). The standard protocols were performed in accordance with approved guidelines[14,17].

\section{Analysis of caspase-3 activity}

HLE, Bel 7402 and PLC/PRF/5 cells were treated with tumor necrosis factor-related apoptosis-induced ligand (TRAIL) $(2 \mu \mathrm{mol} / \mathrm{L})$ or Vinco $(80 \mu \mathrm{g} / \mathrm{ml})$ and a caspase-3 inhibitor (Z-DEVD-FMK, $1.0 \mu \mathrm{mol} / \mathrm{L})$ (Selleck Chemicals Company, USA) for $24 \mathrm{~h}$. Caspase-3 activity was measured with a commercial kit (APOP-CYTO Caspase-3 Colorimetric Assay Kit; Medical and Biological Laboratories, Japan) according to the manufacturer's protocol as described in a previous study[18].

\section{Animal experiments}

Male pathogen-free athymic nude mice were purchased from the Guangzhou Animal Research Center (Guangzhou, China). The animals were maintained in a facility approved by the Ethical Committee of Hainan Medical University. The experimental procedures were approved by the Hainan Medical College Institutional Committee. To analyze tumorigenicity, Bel 7402 and PLC/PRF/ 5 cells $\left(1 \times 10^{6}\right)$ in $0.1 \mathrm{ml}$ of Hank's balanced salt solution were subcutaneously injected into the right scapular region of nude mice (7 per group). The mice were intraperitoneally injected with Vinco $(10 \mathrm{mg} / \mathrm{kg} /$ day) every day. Tumor-bearing mice were killed every 3 days after inoculation, tumorous tissues were removed, the length $(L)$ and weight (W) of the tumors were measured, and the volume $(\mathrm{V})$ was calculated by the following formula as described previously $[19,20], V=\pi / 6 \times L \times W^{2}(\pi=3.14)$. On day 21 , tumorous tissues, and the expression of activated caspase-3, PARP-1, PTEN and p-KAT (Ser473) was detected by immunohistochemical analysis or Western blotting. 


\section{Statistical analysis}

The data are presented as the mean \pm S.D. Statistical analysis was performed using Student's t-test (for two experimental groups). Significance was set at $P<0.05$.

Statistical significance was determined using Student's t-test and the $F$ test (SPSS 11.5 software for Windows, SPSS Inc., Chicago, IL, US).

\section{Results}

\section{Vinco inhibited the proliferation of HCC cells and promoted their apoptosis}

In the MTT assay, L-02, HLE, Bel 7402 and PLC/PRF/ 5 cells were treated with different concentrations of Vinco $(5-80 \mu \mathrm{g} / \mathrm{ml})$ for $48 \mathrm{~h}$. At a concentration of $10 \mu \mathrm{g} / \mathrm{ml}$, Vinco inhibited the proliferation of HLE cells but had little effect on the growth of Bel 7402 and PLC/PRF/5 cells. When the concentration of Vinco was greater than $40 \mu \mathrm{g} / \mathrm{ml}$, the proliferation of HLE, Bel 7402 and PLC/PRF/ 5 cells was significantly suppressed; the results also revealed that Vinco had little effect on normal human liver L-02 cells (Fig. 1A). To further evaluate the role of Vinco in HCC cell apoptosis, L-02, HLE, Bel 7402 and PLC/PRF/5 cells were treated with different concentrations of Vinco $(10 \mu \mathrm{g} / \mathrm{ml}$ or $80 \mu \mathrm{g} / \mathrm{ml})$ for $48 \mathrm{~h}$. We observed changes in cellular morphology by microscopy, and trypan blue exclusion dye was used to analyze cell viability and metabolic activity. The results showed that morphological changes occurred in HLE, Bel 7402 and PLC/PRF/5 cells treated with Vinco (Fig. 1B) and that the number of dead cells in the Vincotreated groups was significantly increased (Fig. 1C) compared to that in the untreated groups. Nuclear morphological changes were observed in HLE, Bel 7402 and PLC/PRF/ 5 cells under a fluorescence microscope using DAPI staining. The results indicated that in Vinco-treated $(10 \mu \mathrm{g} / \mathrm{ml}$ or $80 \mu \mathrm{g} / \mathrm{ml}) \mathrm{HLE}$, Bel 7402 and PLC/PRF/ 5 cells, the degree of cellular nuclear condensation and pyknosis was significantly increased compared to that in untreated cells, and morphological characteristics of apoptosis, including apoptosome formation and nuclear shrinkage, were apparent. However, few changes were observed in the untreated group and in normal liver cell(L-02), and the results revealed that Vinco also promoted apoptosome formation in HCC cells (Fig. 1D). These results indicate that Vinco inhibits the growth of HCC cells and promotes their apoptosis.

\section{Vinco disrupted the morphology and function of mitochondria in HCC cells}

To reveal the mechanism underlying the role of Vinco in suppressing the growth of HCC cells and stimulating their apoptosis, we used electron microscopy to observe morphological and structural changes of mitochondria in HCC cells. HLE, Bel 7402 and PLC/PRF/5 cells were treated with Vinco (80 $\mu \mathrm{g} / \mathrm{ml}$ ) for $48 \mathrm{~h}$, and the results indicated that mitochondrial swelling and ridge breakage occurred in apoptotic HCC cells but the morphology of mitochondria in the untreated groups remained normal (Fig. 2). These results demonstrate that Vinco disrupts the morphology and function of mitochondria in HCC cells. 


\section{Vinco inhibited the migration and invasion of HCC cells}

To observe the effect of Vinco on the migration and invasion of HCC cells, cellular wound repair and invasion assays were performed. In the cellular wound repair assay, HLE, Bel 7402 and PLC/PRF/5 cells were treated with Vinco $(10 \mu \mathrm{g} / \mathrm{ml})$ for $24 \mathrm{~h}$ or $48 \mathrm{~h}$. The scratch repair assay revealed that repair migration of Vinco-treated HLE cells was significantly decreased compared to that of untreated HLE cells. Little change was observed in Bel 7402 and PLC/PRF/5 cells treated with Vinco $(10 \mu \mathrm{g} / \mathrm{ml}$ or $80 \mu \mathrm{g} / \mathrm{ml})$ for $24 \mathrm{~h}$, but when these cells were treated with Vinco $(10 \mu \mathrm{g} / \mathrm{ml})$ for $48 \mathrm{~h}$, their repair migration was significantly decreased compared to that of untreated (control) cells (Fig. 3A). The invasion assay indicated that the pore transfer capacity of HLE, Bel 7402 and PLC/PRF/5 cells treated with Vinco (10 $\mu \mathrm{g} / \mathrm{ml}$ or $80 \mu \mathrm{g} / \mathrm{ml}$ ) for $48 \mathrm{~h}$ was significantly decreased compared to that of untreated cells (control); the results also showed that the pore transfer capacity of HCC cells treated with a high concentration of Vinco $(80 \mu \mathrm{g} / \mathrm{ml})$, was significantly decreased compared to that of HCC cells treated with a low concentration of Vinco $(10 \mu \mathrm{g} / \mathrm{ml})$ (Fig. 3B). These results reveal that Vinco inhibits the migration and invasion of HCC cells in a dose-dependent manner.

Furthermore, we performed Western blotting to explore the effect of Vinco on the expression of migrationand invasion-related proteins. The results revealed that in HLE cells treated with Vinco $(10 \mu \mathrm{g} / \mathrm{ml}$ or 80 $\mu \mathrm{g} / \mathrm{ml}$ ) for $48 \mathrm{~h}$, the expression of MMP9, CXCR4 and EpCAM was significantly reduced compared to that in untreated cells(control). The expression of these proteins was also significantly lower in HLE cells treated with a high concentration of Vinco $(80 \mu \mathrm{g} / \mathrm{ml})$ than in those treated with a low concentration of Vinco $(10 \mu \mathrm{g} / \mathrm{ml})$. In Bel 7402 cells treated with Vinco $(10 \mu \mathrm{g} / \mathrm{ml}$ or $80 \mu \mathrm{g} / \mathrm{ml})$ for $48 \mathrm{~h}$, the expression of MMP9 and CXCR4 was significantly reduced compared to that in untreated cells(control), and the expression of these proteins was also significantly lower in Bel 7402 cells treated with a high concentration of Vinco $(80 \mu \mathrm{g} / \mathrm{ml})$ than that in those treated with a low concentration of Vinco $(10$ $\mu \mathrm{g} / \mathrm{ml})$. However, there was little change in the expression of EpCAM in Bel 7402 cells. In PLC/PRF/ 5 cells treated with Vinco $(10 \mu \mathrm{g} / \mathrm{ml}$ or $80 \mu \mathrm{g} / \mathrm{ml})$ for $48 \mathrm{~h}$, the expression of CXCR4 and EpCAM was significantly reduced compared to that in untreated cells(control), and the expression of these proteins was also significantly lower in PLC/PRF/5 cells treated with a high concentration of Vinco $(80 \mu \mathrm{g} / \mathrm{ml})$ than in those treated with a low concentration of Vinco $(10 \mu \mathrm{g} / \mathrm{ml})$. However, there was little change in the expression of MMP9 in PLC/PRF/5 cells (Fig. 3C). These results demonstrate that Vinco inhibits the expression of migration- and invasion-related proteins.

\section{Vinco activated caspase-3 activity in HCC cells}

Activated caspase-3 activity is a pivotal factor for the promotion of cell apoptosis. In the present investigation, we applied laser confocal microscopy to observe the expression, location and migration of caspase-3. The results showed that HLE, Bel 7402 and PLC/PRF/ 5 cells expressed caspase- 3 and that the caspase-3 protein was located in the cytoplasm in these cells. The results also showed that a small amount of caspase-3 migrated from the cytoplasm to nucleus when the cells were treated with a low concentration of Vinco $(10 \mu \mathrm{g} / \mathrm{ml})$ for $48 \mathrm{~h}$. However, a large amount of caspase-3 was assembled in the 
nucleus when the cells were treated with a high concentration of Vinco $(80 \mu \mathrm{g} / \mathrm{ml})$ for $48 \mathrm{~h}$ (Fig. 4A). To explore the effect of Vinco on the expression of apoptosis-related proteins, Western blotting was used to detect the expression of Bax, Bcl-2, activated caspase-3 and PARP-1. The results indicated that in HLE, Bel 7402 and PLC/PRF/ 5 cells treated with Vinco $(10 \mu \mathrm{g} / \mathrm{ml}$ or $80 \mu \mathrm{g} / \mathrm{ml})$ for $48 \mathrm{~h}$ compared to untreated cells, the expression of Bax was significantly stimulated, the expression of Bcl-2 was significantly inhibited, and the expression of activated caspase-3 and PARP-1 was significantly promoted (Fig. 4B). The Bax/Bcl-2 ratio was also elevated in cells treated with Vinco $(10 \mu \mathrm{g} / \mathrm{ml}$ or $80 \mu \mathrm{g} / \mathrm{ml})$, but the elevation in the ratio was more significant in cells treated with a high concentration of treated with Vinco (80 $\mu \mathrm{g} / \mathrm{ml})$ than in those treated with a low concentration of Vinco $(10 \mu \mathrm{g} / \mathrm{ml})(\mathrm{Fig} .4 \mathrm{C})$. Furthermore, we analyzed the effect of Vinco on the activity of caspase-3. HLE, Bel 7402 and PLC/PRF/5 cells were treated with tumor necrosis factor-related apoptosis-induced ligand(TRAIL), which promotes TRAIL receptor-mediated caspase-3 activity, as a positive control and Z-DEVD-FMK, which inhibits caspase-3 activity, for $48 \mathrm{~h}$. The results revealed that Vinco $(80 \mu \mathrm{g} / \mathrm{ml})$ activated caspase-3 activity similarly to TRAIL $(2 \mu \mathrm{mol} / \mathrm{L})$ and that the inhibitor (Z-DEVD-FMK) blocked the effect of Vinco. Vinco synergized with TRAIL to stimulate caspase-3 activity (Fig. 4D). These results demonstrate that Vinco has the capacity to activate caspase-3.

\section{Vinco blocked the PI3K/AKT signaling pathway and inhibited the expression of oncogenes}

In the present study, we explored the effect of Vinco on the PI3K/AKT signaling pathway and the expression of oncogenes. HLE, Bel 7402 and PLC/PRF/ 5 cells were treated with Vinco $(80 \mu \mathrm{g} / \mathrm{ml})$ for 48 $h$, and the expression and location of PTEN, Src and Oct4 were observed by laser confocal microscopy. The results indicated that Vinco promoted the expression of PTEN and that PTEN was located in the cytoplasm (Fig. 5A). The expression of Src and Oct4 was significantly inhibited, Src was located in the cytoplasm and Oct4 was located in the nucleus (Fig. $6 \mathrm{~A}$ and B). We also used Western blotting to detect the expression of PTEN and other molecules related to the PI3K/AKT signaling. The results revealed that the expression of PTEN was significantly stimulated and that the expression of pAKT (Ser473), pmTOR (Thr2448) was significantly inhibited when these cells was treated with Vinco $(10 \mu \mathrm{g} / \mathrm{ml}$ or $80 \mu \mathrm{g} / \mathrm{ml})$ for $48 \mathrm{~h}$. Additionally, a high concentration of Vinco $(80 \mu \mathrm{g} / \mathrm{ml})$ had a greater effect on suppressing the expression of pAKT (Ser473) and pmTOR (Thr2448) in HCC cells (Fig. 5B). Vinco not only inhibited the

expression of pAKT (Ser473), Src and Oct4, but also synergized with a PI3K inhibitor (Ly294002) to inhibit the expression of pAKT (Ser473), Src and Oct4 (Fig. 6B). These results prove that Vinco is able to block the activation of the PI3K/AKT signaling pathway and inhibit the expression of oncogenes in vitro.

\section{Vinco inhibited cancer growth, activated caspase-3 activity and blocked the PI3K/AKT signaling pathway in vivo}

In the present study, the therapeutic effect of Vinco in a tumor model was observed by injecting Bel 7402 and PLC/PRF/ 5 cells into the right scapular region of male nude mice. The mice were intraperitoneally injected with Vinco (10 mg/kg/day) every day, tumor-bearing mice were killed every 3 days after inoculation, and the tumor volume was calculated. The results showed that the tumor volume of Vinco- 
treated mice was significantly reduced compared to that of untreated mice(control) at the same time point after 9 days (Fig. 7A and B). Furthermore, immunohistochemical analysis was applied to detect the expression of c-Myc, Ras, activated caspase- 3 and PARP- 1 in tumorous tissues at 21 days. The results indicated that the expression of c-Myc and Ras was significantly decreased in tissues from Vinco-treated mice compared to tissues from untreated mice but that the expression of activated caspase- 3 and PARP1 was significantly elevated in tissues from Vinco-treated mice compared to tissues from untreated mice (Fig. 7C and D). Western blotting revealed that the expression of activated caspase-3, PARP-1 and PTEN was significantly elevated in tissues from Vinco-treated mice compared to tissues from untreated mice but that the expression of p-AKT (Ser473) was significantly decreased (Fig. 7E). These results further demonstrate that Vinco inhibits the growth of liver cancer, activates caspase- 3 and blocks transduction of PI3K/AKT signaling pathway.

\section{Discussion}

Monoterpene indolic alkaloid ( $\mathrm{N}$ - $\beta$-glucopyranosyl vincosamide) is the main component of extracts of the leaves of Psychotria leiocarpa, which is found in tropical and subtropical regions. Many studies have shown that Vinco has anti-inflammatory activities in vivo and anti-proliferative effects in vitro[1, 6, 21, 22], and Vinco also has cytotoxic and anti-bactericidal activities[2,23]. Some investigations over the past three decades have indicated that Vinco inhibits the proliferation of cancer cells and promotes their apoptosis[3,24] and that it protects against doxorubicin-induced cardiotoxicity in rats in vitro and in vivo[9]. This evidence indicates that Vinco plays a complex role in regulating anti-inflammatory and antibacterial activities and protecting against cardiotoxicity.

Although evidence has revealed that an analog of Vinco induces cytotoxicity in human leukemic and rat hepatoma cell lines[24], inhibits the growth of a glioma cell line (U251)[2] and has anti-oxidant activity to protect against oxidative stress generated upon wounding[6]; the effect of Vinco on the malignant behaviors of human HCC cells is still unclear. In the present study, we observed the cytotoxicity of Vinco in human HCC cells and human normal liver cells. The results of the MTT and trypan blue exclusion assays revealed that Vinco significantly inhibited the growth of HCC cells and promoted their death at concentrations greater than $40 \mu \mathrm{g} / \mathrm{ml}$ but had little cytotoxicity in normal liver cells. DAPI staining also showed that Vinco promoted apoptosome formation in the nucleus. Additionally, the cellular wound repair and invasion assays indicated that Vinco significantly suppressed the migration and invasion of HCC cells. To our surprise, the low concentration of Vinco $(10 \mu \mathrm{g} / \mathrm{ml})$ inhibited the growth of HLE cells, implying that the sensitivity of different HCC cells to Vinco is different, possibly due to their heterogeneity. We previously found that HLE cells are more sensitive than other HCC cells to other agents, such as benzyl isothiocyanate and paclitaxel, due to the lower expression of alpha fetoprotein (AFP) in HLE cells compared to that in Bel 7402 and PLC/PRF/ 5 cells, and that AFP has an antagonistic effect on the ability of these drugs to induce apoptosis of HCC cells $[12,25]$. However, these results also demonstrate that Vinco has the capacity to inhibit growth and invasion and stimulate apoptosis of HCC cells. 
To explore the mechanism underlying the ability of Vinco to suppress the malignant behaviors of HCC cells, we evaluated changes in the morphology and function of cellular mitochondria. The results indicated that Vinco significantly disrupted mitochondrial morphology. Western blotting analysis displayed that the expression of Bcl-2 was significantly suppressed, the expression of Bax, cleaved caspase-3, and PARP-1 was significantly stimulated, and caspase-3 was activated. Vinco also promoted the migration of activated caspase- 3 from the cytoplasm to the nucleus. These results suggest that Vinco is able to impair the function of mitochondria in HCC cells and activate caspase-3 in vitro. The activated $\mathrm{PI} 3 \mathrm{~K} / \mathrm{AKT}$ signaling pathway is a pivotal factor for promoting the proliferation, drug resistance, and metastasis of HCC cells[26-28]. Recently, many studies have indicated that the activated PI3K/AKT signaling pathway is able to stimulate the expression of malignant behavior-related genes, such as Src, CXCR4, MMP2/9, and EpCAM [29-32]. PTEN is critical for inhibiting the activation of the PI3K/AKT signaling pathway in HCC cells[33-36]. The results of this study indicate that Vinco inhibits the expression of Src, CXCR4, MMP9 and EpCAM, and stimulates the expression of PTEN, leading to the inhibition of pAKT (Ser473) and pmTOR (Thr2448) expression. These results reveal that Vinco-mediated inhibition of PI3K/AKT signaling pathway transduction is critical for suppressing the malignant behaviors of HCC cells.

Vinco has the capacity to inhibit the proliferation of HCC cells in vitro, but whether it has the same effect in vivo is still unclear. In the present study, we observed the therapeutic effect of Vinco in an animal tumorous model. Animal tumorous models were administered Vinco $(10 \mathrm{mg} / \mathrm{kg} /$ day $)$ every day. Because HLE cells can not induce tumors production when transplanted into mice, only Bel 7402 and PLC/PRF cells were selected to inject into the mice. The results showed that the tumor volume of Vinco-treated mice was significantly reduced compared to that of untreated mice. The results also showed that the expression of c-Myc, Ras, and PAKT (Ser473) significantly decreased in tissues from Vinco-treated mice compared to those from untreated mice, but the expression of activated caspase-3, PARP-1 and PTEN was significantly elevated. These results further prove that Vinco suppresses the growth of liver cancer cells and is able to activate caspase-3, and stimulate the expression of PTEN to block the transduction of $\mathrm{PI} 3 \mathrm{~K} / \mathrm{AKT}$ signaling pathway in vivo. We have summarized the mechanism underlying the role of Vinco in inhibiting the malignant behaviors of HCC cells (Fig. 8).

In conclusion, the present study showed for the first time that Vinco has a therapeutic effect in inhibiting the malignant behaviors of HCC cells. The mechanism of Vinco may involve in activating the activity of caspase- 3 and blocking the transdcution of PI3K/AKT signaling pathway. Vinco is a natural drug that can be used alone or in combination with other drugs for treating HCC patients.

\section{Abbreviations}

HCC: Hepatocellular carcinoma; Vinco: Vincosamide; AFP: Alpha fetoprotein; TRAIL: Tumor necrosisrelated apoptosis-induced ligand; PTEN: phosphate and tension homology deleted on chromsome ten.

\section{Declarations}


Acknowledgements

We thank Dr. Wenting Wang for assisting in the cellular migration assays.

\section{Authors' contributions}

$M L$ and $M Z$ designed the experiments. $M Z, H F, B L, Y Z, Y F Z$ and $K L$ performed the experiment. $M L$ and $M Z$ supervised the study, analysis the data. ML written the manuscript. All authors read and approved the final manuscript.

\section{Funding}

This work was supported by the National Natural Science Foundation of China (Nos. 81960519, 81660463, 81560450, 31560243); the Natural Science Foundation of Hainan Province (Nos. 2019CXTD406, 2019CR204 and 20168263); and Hainan Provincial Association for Science and Technology Program of Youth Science Talent and Academic Innovation (No. QCXM 201922).

\section{Availability of data and materials}

All data generated or analyzed during this study are included in this manuscript.

\section{Ethics approval and consent to participate}

All animal experiments were approved by the Institutional Animal Care and

Use Committee at the Hainan Medical University, Haikou, Hainan Province, PR. China.

\section{Consent for publication}

All authors have read and agreed to publish this manuscript.

\section{Competing interests}

All the authors confirm that no conflicts of interest are associated with the content of this article.

\section{Author details}

${ }^{1}$ Hainan Provincial Key Laboratory of Carcinogenesis and Intervention, Hainan Medical University, Hiakou 571199, Hainan Province, PR. China

${ }^{2}$ Institution of Tumor, Hainan Medical University, Hiakou 570102, Hainan Province, PR. China

\section{References}

1. Marques de Oliveira A, Lyra Lemos RP, Conserva LM. $\beta$-Carboline alkaloids from Psychotria barbifloraDC. (Rubiaceae). Biochem Syst Ecol. 2013;50:339-41. 
2. de Moura VM, Ames FQ, Corrêa JGS, Peixoto MA, Amorim AMA, Pomini AM, de Carvalho JE, Ruiz ALTG, Bersani-Amado CA, Santin SMO. Cytotoxicity and anti-inflammatory effects of the extract, fractions and alkaloids from Palicourea minutiflora(Rubiaceae). Nat Prod Res. 2020;9:1-5.

3. Volobuff CRF, Junior PCO, Dos Santos SM, Pereira ZV, Ferreira DC, Cardoso CAL, Ruiz ALTG, Foglio MA, de Carvalho JE, Formagio ASN. Antitumoral and anticholinesterasic activities of the seven species from Rubiaceae. Curr Pharm Biotechnol. 2019;20(4):302-8.

4. Formagio ASN, Volobuff CRF, Kassuya CAL, Cardoso CAL, do Carmo Vieira M, Pereira ZV, Bagatin MC, de Freitas Gauze G. Psychotria leiocarpa extract and Vincosamide reduce chemically-induced inflammation in mice and inhibit the acetylcholinesterase activity. Inflammation. 2019; 42(5):156174.

5. Caballero-George C, Vanderheyden PML, Solis PN, Pieters L, Shahat AA, Gupta MP, Vauquelin G, Vlietnick AJ. Biological screening of selected medicinal Panamenian plants byradioligand-binding techniques. Phytomedicine. 2001;8:59-70.

6. Matsuura HN, Fett-Neto AG. The major indole alkaloid N, $\beta$-D-glucopyranosyl vincosamide from leaves of Psychotrialeiocarpa Cham. \& Schltdl. Is not an antifeedant but shows broad antioxidant activity. Nat Product Res. 2013;27:402-11.

7. Moraes TMS, de Araújo MH, Bernardes NR, de Oliveira DB, Lasunskaia EB, Muzitano MF, da Cunha M. Antimycobacterial activity and alkaloid prospection of Psychotriaspecies (Rubiaceae) from the Brazilian Atlantic Rainforest. Planta Med. 2011;77:964-70.

8. McKenna DJ, Towers GN, Abbot F. Monoamineoxidase inhibitors in South American hallucinogenic plants:trypatamine and $\beta$-carboline constituents of Ayahusca. J Ethnopharmacol. 1984;10:195-223.

9. Cheraghi M, Namdari M, Daraee H, Negahdari B. Cardioprotective effect of magnetic hydrogel nanocomposite loaded N,a-L-rhamnopyranosyl vincosamide isolated from Moringa oleifera leaves against doxorubicin-induced cardiac toxicity in rats: in vitro and in vivo studies. J Microencapsul. 2017;34(4):335-41.

10. Li MS, Li PF, Yang FY, He SP, Du GG, Li G. The intracellular mechanism of alpha-fetoprotein promoting the proliferation of NIH 3T3 cells. Cell Res. 2002;12(2):151-6.

11. Zhu M, Li W, Lu Y, Dong X, Lin B, Chen Y, Zhang X, Guo J, Li M. HBx drives alpha fetoprotein expression to promote initiation of liver cancer stem cells through activating PI3K/AKT signal pathway. Int J Cancer. 2017;140(6):1346-55.

12. Zhu M, Li W, Guo J, Lu Y, Dong X, Lin B, Chen Y, Zhang X, Li M. Alpha fetoprotein antagonises benzyl isothiocyanate inhibition of the malignant behaviors of hepatocellular carcinoma cells. Oncotarget. 2016;7(46):75749-62.

13. Zhu M, Lu Y, Li W, Guo J, Dong X, Lin B, Chen Y, Xie X, Li M. Hepatitis B virus X protein driven alpha fetoprotein expression to promote malignant behaviors of normal liver cells and hepatoma cells. $J$ Cancer. 2016;7(8):935-46.

14. Feng H, Zhu M, Zhang R, Wang Q, Li W, Dong X, Chen Y, Lu Y, Liu K, Lin B, Guo J, Li M. GATA5 inhibits hepatocellular carcinoma cells malignant behaviours by blocking expression of reprogramming 
genes. J Cell Mol Med. 2019;23(4):2536-48.

15. Wang W, Zhu M, Xu Z, Li W, Dong X, Chen Y, Lin B, Li M. Ropivacaine promotes apoptosis of hepatocellular carcinoma cells through damagingmitochondria and activating caspase- 3 activity. Biol Res. 2019;52(1):36.

16. Li M, Zhu M, Li W, Lu Y, Xie X, Wu Y, Zheng S. Alpha-fetoprotein receptor as an early indicator of HBx-driven hepatocarcinogenesis and its applications in tracing cancer cell metastasis. Cancer Lett. 2013;330(2):170-80.

17. Lu Y, Zhu M, Li W, Lin B, Dong X, Chen Y, Xie X, Guo J, Li M. Alpha fetoprotein plays a critical role in promoting metastasis of hepatocellular carcinoma cells. J Cell Mol Med. 2016;20(3):549-58.

18. Li M, Li H, Li C, Zhou S, Guo L, Liu H, Jiang W, Liu X, Li P, McNutt MA, Li G. Alpha fetoprotein is a novel protein-binding partner for caspase 3 and blocks the apoptotic signaling pathway in human hepatoma cells. Int J Cancer. 2009;124(12):2845-54.

19. Euhus DM, Hudd C, LaRegina MC, Johnson FE. Tumor measurement in the nude mouse. J Surg Oncol. 1986;31(4):229-34.

20. Tomayko MM, Reynolds CP. Determination of subcutaneous tumor size in athymic (nude) mice. Cancer Chemother Pharmacol. 1989;24(3):148-54.

21. Benevides PJC, Young MCM, Bolzani VDS. Biological Activities of Constituentsfrom Psychotriaspectabilis. Pharm Biol. 2004;42:565-9.

22. Li D, Chen J, Ye J, Zhai X, Song J, Jiang C, Wang J, Zhang H, Jia X, Zhu F. Anti-inflammatory effect of the six compounds isolated from Nauclea officinalis Pierrcex Pitard, and molecular mechanism of strictosamide via suppressing the NF-KB and MAPK signaling pathway in LPS-induced RAW 264.7 macrophages. J Ethnopharmacol. 2017;196:66-74.

23. Mahmud Z, Musa M, Ismail N, Lajis NH. Cytotoxic and bacteriocidal activities of Psychotria rostrata. Int J Pharmacogn. 1993;31:142-6.

24. Adjibade Y, Kuballa B, Cabalion P, Jung ML, Beck JP, Anton R. Cytotoxicity on human leukemic andrat hepatoma cell lines of alkaloid extracts of Psychotria forsteriana. Planta Med. 1989;55:567-8.

25. Zhu M, Li W, Lu Y, Dong X, Chen Y, Lin B, Xie X, Guo J, Li M. Alpha fetoprotein antagonizes apoptosis induced by paclitaxel in hepatoma cells in vitro. Sci Rep. 2016;6:26472.

26. Tu K, Liu Z, Yao B, Han S, Yang W. MicroRNA-519a promotes tumor growth by targeting PTEN/PI3K/AKT signaling in hepatocellular carcinoma. Int J Oncol. 2016;48(3):965-74.

27. Fu X, Liu M, Qu S, Ma J, Zhang Y, Shi T, Wen H, Yang Y, Wang S, Wang J, Nan K, Yao Y, Tian T. Exosomal microRNA-32-5p induces multidrug resistance in hepatocellular carcinoma via the PI3K/Akt pathway. J Exp Clin Cancer Res. 2018;37(3):52.

28. Li X, Yang Z, Song W, Zhou L, Li Q, Tao K, Zhou J, Wang X, Zheng Z, You N, Dou K, Li H. Overexpression of Bmi-1 contributes to the invasion and metastasis of hepatocellular carcinoma by increasing the expression of matrix metalloproteinase (MMP)2, MMP-9 and vascular endothelial growth factor via the PTEN/PI3K/Akt pathway. Int J Oncol. 2013;43(1):793-802. 
29. Xia H, Ooi LL, Hui KM. MicroRNA-216a/217-induced epithelial-mesenchymal transition targets PTEN and SMAD7 to promote drug resistance and recurrence of liver cancer. Hepatology. 2013;58(2):629-41.

30. O'Brien NA, Browne BC, Chow L, Wang Y, Ginther C, Arboleda J, Duffy MJ, Crown J, O'Donovan N, Slamon DJ. Activated phosphoinositide 3-kinase/AKT signaling confers resistance to trastuzumab but not lapatinib. Mol Cancer Ther. 2010;9(6):1489-502.

31. Zhu M, Guo J, Li W, Lu Y, Fu S, Xie X, Xia H, Dong X, Chen Y, Quan M, Zheng S, Xie K, Li M. Hepatitis B virus $X$ protein induces expression of alpha-fetoprotein and activates $\mathrm{PI} 3 \mathrm{~K} / \mathrm{mTOR}$ signaling pathway in liver cells. Oncotarget. 2015;6(14):12196-208.

32. Tian T, Nan KJ, Guo H, Wang WJ, Ruan ZP, Wang SH, Liang X, Lu CX. PTEN inhibits the migration and invasion of HepG2 cells by coordinately decreasing MMP expression via the PI3K/Akt pathway. Oncol Rep. 2010;23(6):1593-600.

33. Chen WT, Zhu G, Pfaffenbach K, Kanel G, Stiles B, Lee AS. GRP78 as a regulator of liver steatosis and cancer progression mediated by loss of the tumor suppressor PTEN. Oncogene. 2014;33(42):49975005.

34. Zhu L, Sun Y, Zhang S, Wang L. Rap2B knockdown suppresses malignant progression of hepatocellular carcinoma by inactivating the PTEN/PI3K/Akt and ERK1/2 pathways. Mol Cell Biochem. 2020;466(1-2):55-63.

35. Wang S, Zhu M, Wang Q, Hou Y, Li L, Weng H, Zhao Y, Chen D, Ding H, Guo J, Li M. Alpha-fetoprotein inhibits autophagy to promote malignant behaviour in hepatocellular carcinoma cells by activating PI3K/AKT/mTOR signalling. Cell Death Dis. 2018;9(10):1027.

36. Fu X, Wen H, Jing L, Yang Y, Wang W, Liang X, Nan K, Yao Y, Tian T. MicroRNA-155-5p promotes hepatocellular carcinoma progression by suppressing PTEN through the PI3K/Akt pathway. Cancer Sci. 2017;108(4):620-31.

\section{Figures}



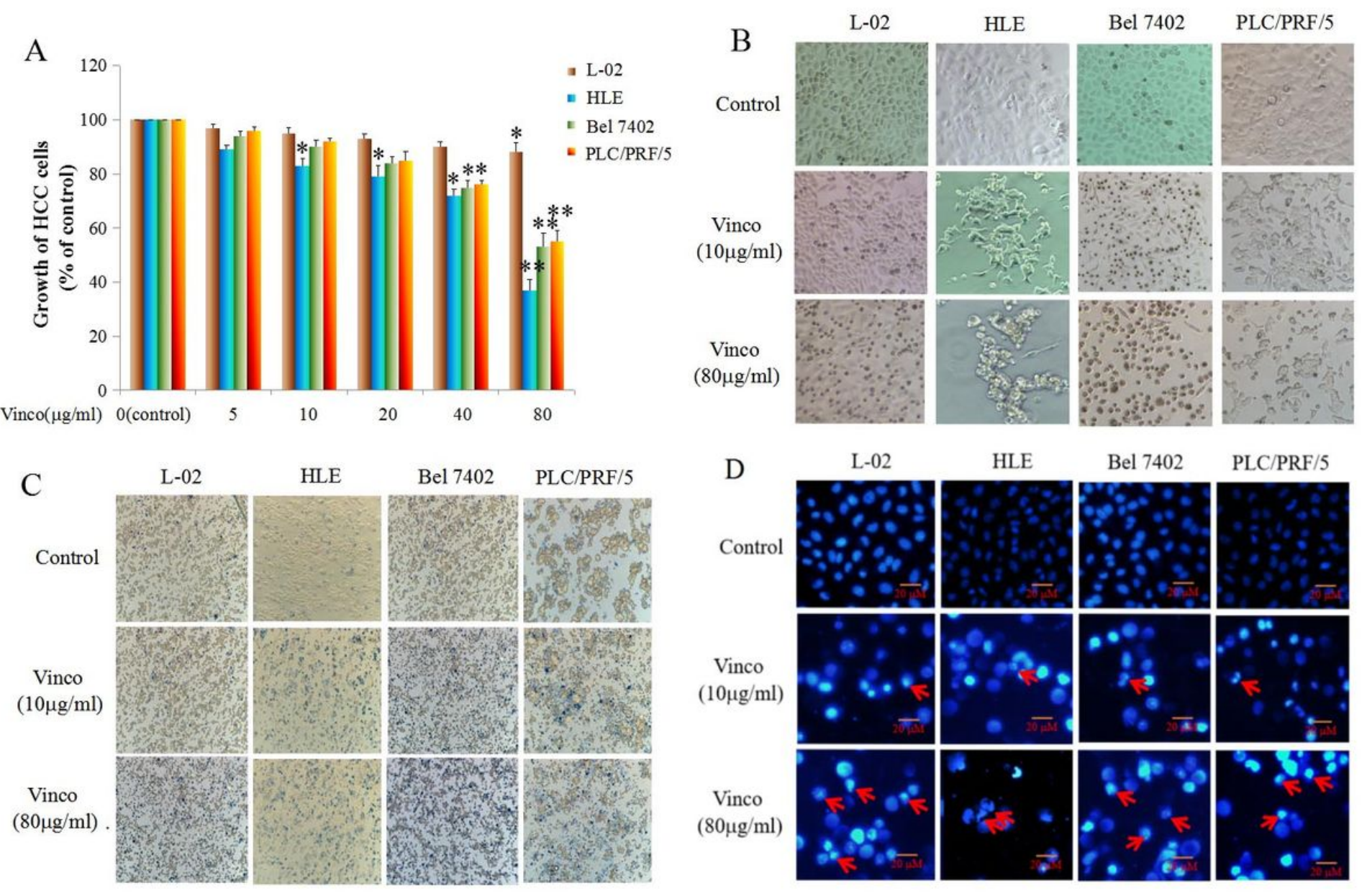

PLC/PRF/5

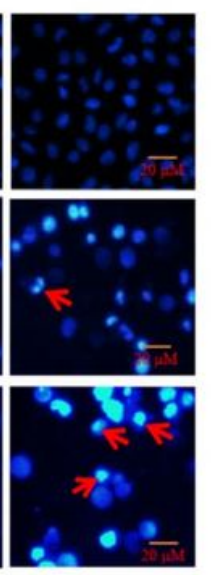

\section{Figure 1}

Influence of Vinco on the growth and apoptosis of the normal liver cell line L-02 and the HCC cell lines HLE, Bel 7402 and PLC/PRF/5. A, L-02 cells and the HCC cell lines HLE, Bel 7402 and PLC/PRF/5 were treated with different concentrations $(5 \mu \mathrm{g} / \mathrm{ml}, 10 \mu \mathrm{g} / \mathrm{ml}, 20 \mu \mathrm{g} / \mathrm{ml}, 40 \mu \mathrm{g} / \mathrm{ml}$ or $80 \mu \mathrm{g} / \mathrm{ml})$ of Vinco for 48 h. The MTT assay was applied to detect the growth of the cells. ${ }^{*}<0.05$ and ${ }^{*} \mathrm{P}<0.01$ vs the control groups $(0 \mu \mathrm{g} / \mathrm{ml}) . \mathrm{N}=6 . \mathrm{L}-02, \mathrm{HLE}, \mathrm{Bel} 7402$ and PLC/PRF/ 5 cells were treated with different concentrations $(10 \mu \mathrm{g} / \mathrm{ml}$ or $80 \mu \mathrm{g} / \mathrm{ml})$ of Vinco for $48 \mathrm{~h}$, and the morphology of these cells was observed by microscopy (B). The trypan blue exclusion dye assay was used to analyze the apoptosis of these cells (C). The nuclei of these cells were stained with DAPI and observed by fluorescence microscopy (D). The red arrows indicate cellular apoptosomes. The images are representative of at least three independent experiments. 

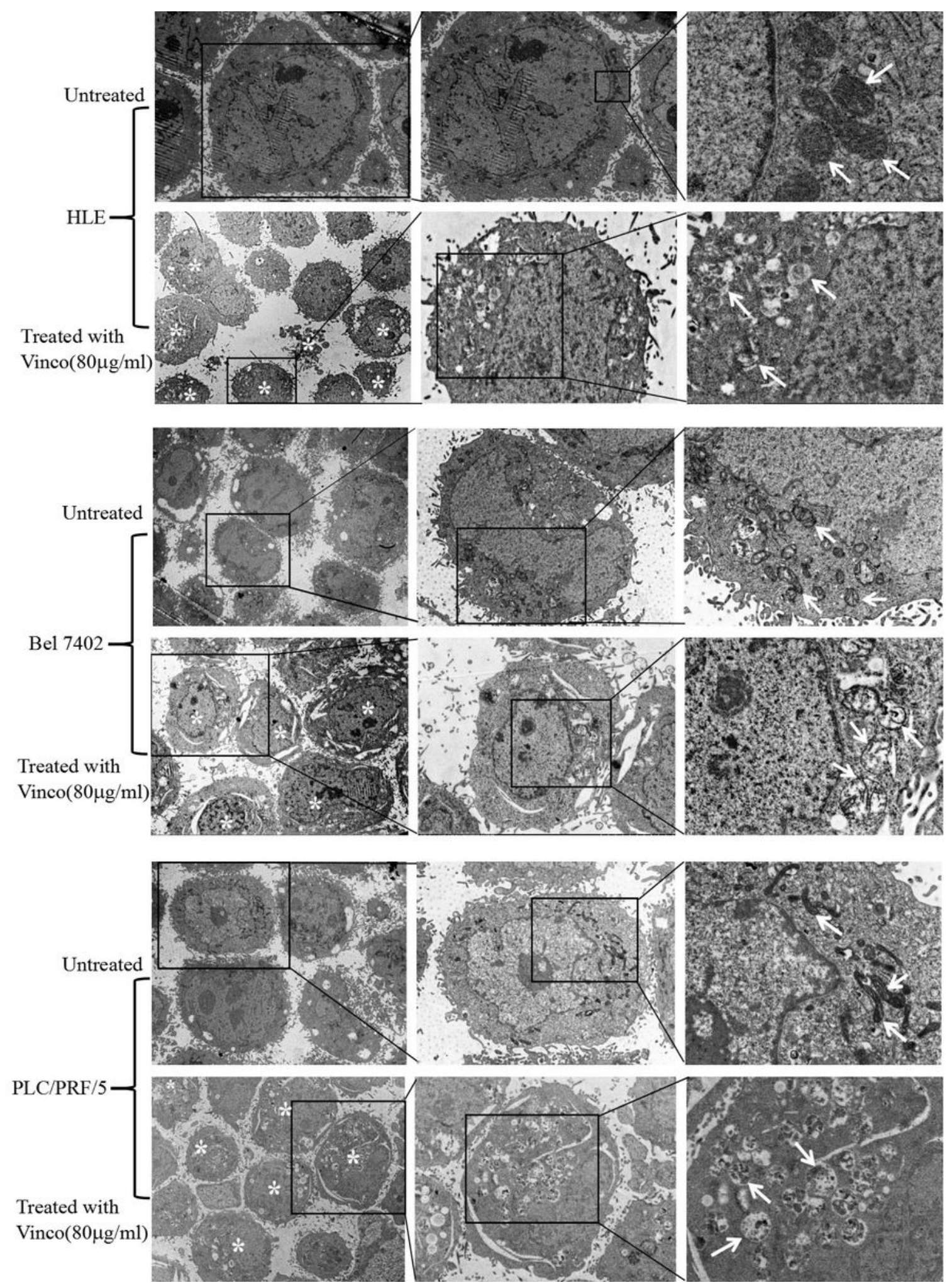

\section{Figure 2}

Effects of Vinco on mitochondrial morphology and function in HLE, Bel 7402 and PLC/PRF/5 cells. HCC cells were treated with Vinco $(80 \mu \mathrm{g} / \mathrm{ml})$ for $12 \mathrm{~h}$, and changes in the morphology of mitochondria in the cells were observed by electron microscopy. *Indicates apoptotic cells, and the white arrows indicate mitochondria. The images are representative of three independent experiments. 
A

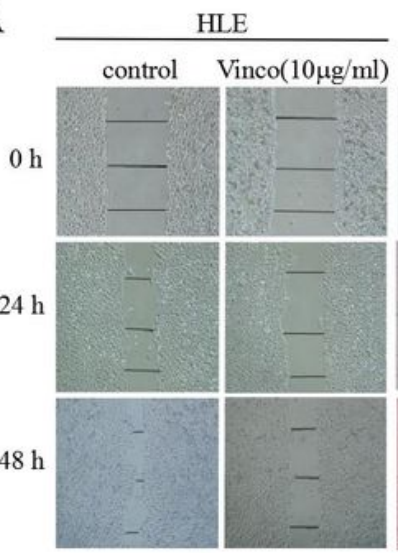

Bel 7402

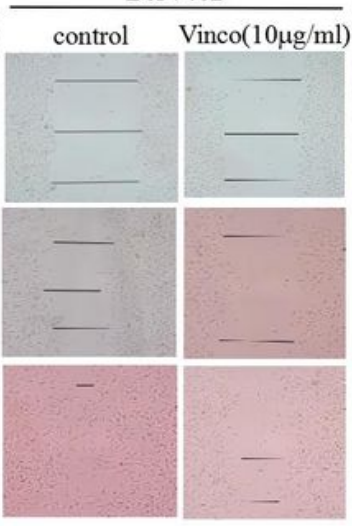

PLC/PRF/5

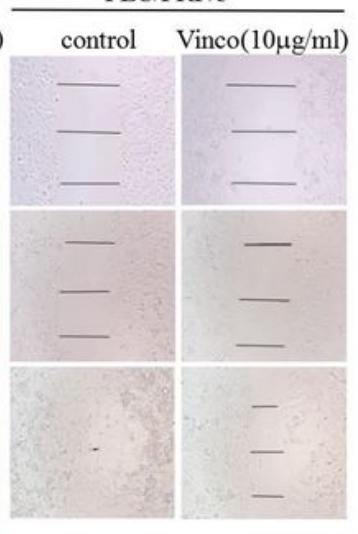

(1)

- Control

- Vinco $(10 \mu \mathrm{g} / \mathrm{ml})$

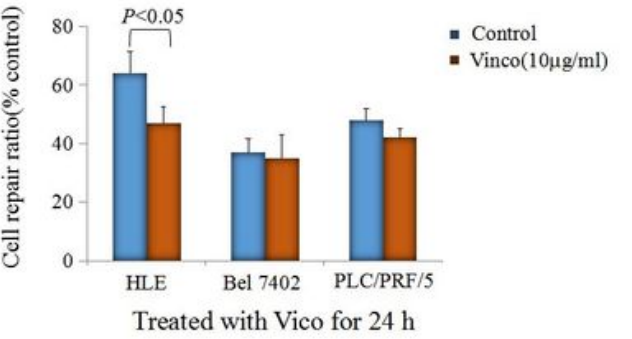

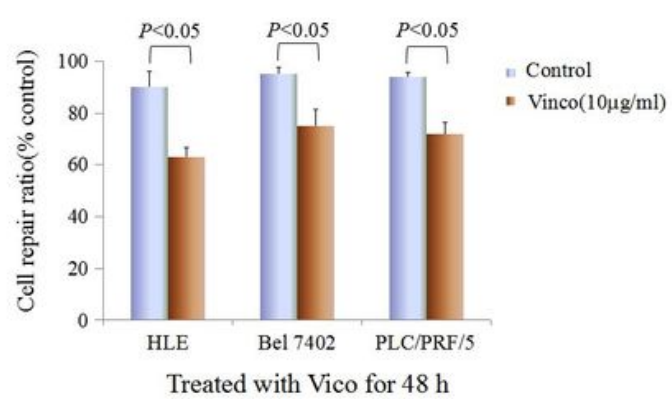
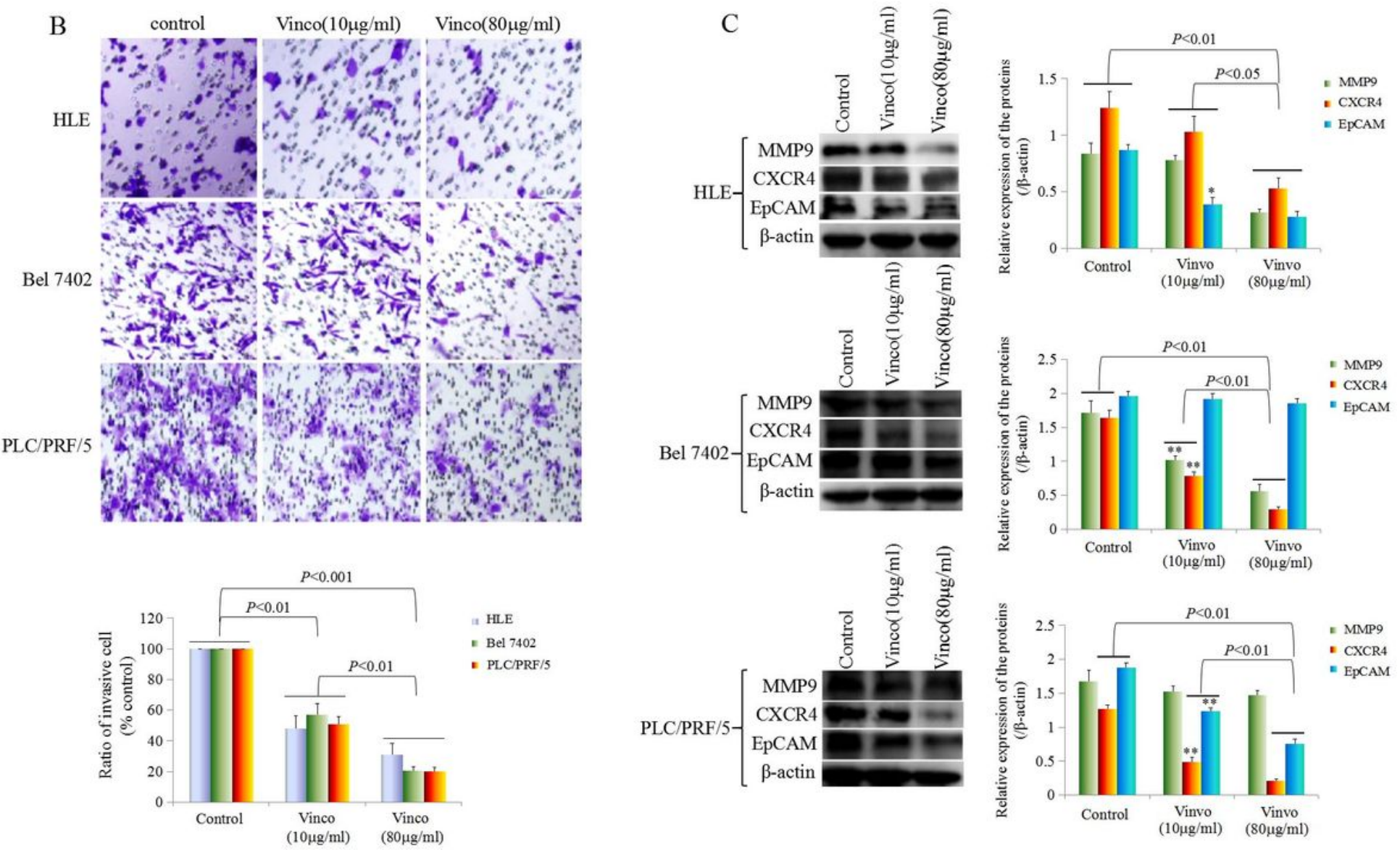

\section{Figure 3}

Influence of Vinco on scratch repair and migration and the expression of metastasis-related proteins in HCC cells. A, HLE, Bel 7402 and PLC/PRF/5 cells were treated with Vinco $(10 \mu \mathrm{g} / \mathrm{ml})$ for $24 \mathrm{~h}$ or $48 \mathrm{~h}$. Scratch repair was observed by microscopy. The bar graph on the right shows the repair ratio of the cells, with $\mathrm{P}<0.05$ indicating statistical significance. $\mathrm{B}, \mathrm{HLE}, \mathrm{Bel} 7402$ and $\mathrm{PLC} / \mathrm{PRF} / 5$ cells were treated with Vinco $(10 \mu \mathrm{g} / \mathrm{ml}$ or $80 \mu \mathrm{g} / \mathrm{ml})$ for $48 \mathrm{~h}$. Migratory cells were stained with $0.1 \%$ crystal violet and observed by microscopy. The lower bar graph show the number of migratory cells. $\mathrm{P}<0.05$ indicates statistical 
significance. C, HLE, Bel 7402 and PLC/PRF/5 cells were treated with Vinco $(10 \mu \mathrm{g} / \mathrm{ml}$ or $80 \mu \mathrm{g} / \mathrm{ml})$ for 48 $\mathrm{h}$, and the expression of the metastasis-related proteins MMP9, CXCR4 and EpCAM was detected by Western blotting. The bar graphs on the right show the relative expressed quantity of these proteins, with $\mathrm{P}<0.05$ indicating statistical significance. The images are representative of three independent experiments.
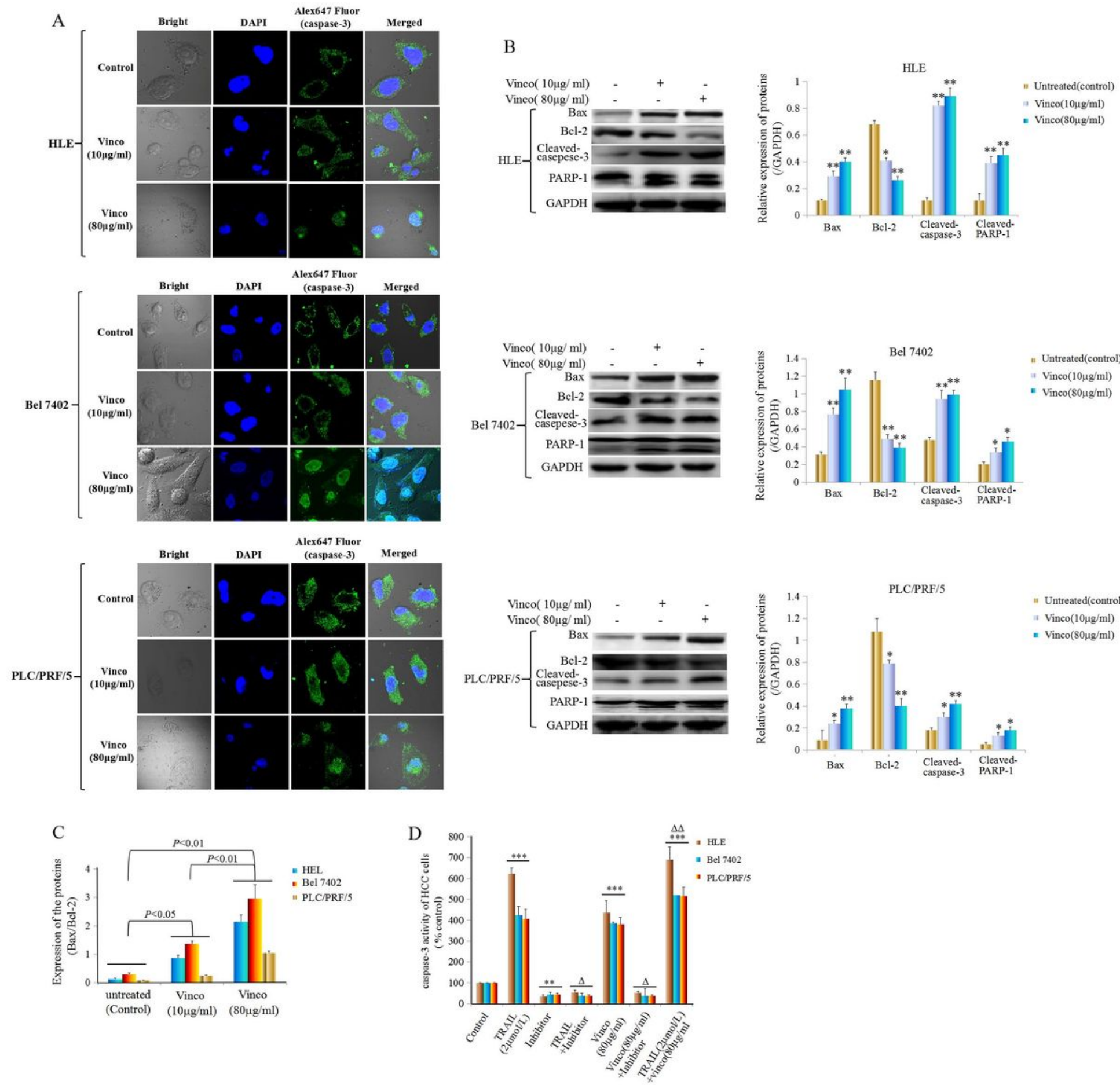

\section{Figure 4}

Effects of Vinco on nuclear migration and activity of caspase-3, and the expression of apoptosis-related proteins in HCC cells. HLE, Bel 7402 and PLC/PRF/5 cells were treated with Vinco $(10 \mu \mathrm{g} / \mathrm{ml}$ or $80 \mu \mathrm{g} / \mathrm{ml})$ 
for $48 \mathrm{~h}$, and the nuclear migration of caspase-3 in these cells was observed by laser confocal microscopy (A). The expression of the apoptosis-related proteins Bax, Bcl-2, cleaved caspase-3 and PARP1 was detected by Western blotting. The bar graphs on the right show the expression of these proteins (B). ${ }^{*} \mathrm{P}<0.05,{ }^{*} \mathrm{P}<0.01$ vs the untreated group(control). The quantitative expression ratio of $\mathrm{Bax} / \mathrm{Bcl}-2$ (C). The images are representative of at least three independent experiments. D, HLE, Bel 7402 and PLC/PRF/ 5 cells were treated with TRAIL $(2 \mu \mathrm{mol} / \mathrm{L})$ or Vinco $(80 \mu \mathrm{g} / \mathrm{ml})$ and a caspase-3 inhibitor (ZDEVD-FMK) for $48 \mathrm{~h}$. The activity of caspase-3 in these cells was measured using an enzymatic reaction kit. ${ }^{*} \mathrm{P}<0.01,{ }^{*} * \mathrm{P}<0.001$ vs control group, $\triangle \mathrm{P}<0.01$ vs the control group, TRAIL $(2 \mu \mathrm{mol} / \mathrm{L})$-treated group or Vinco $(80 \mu \mathrm{g} / \mathrm{ml})$-treated group; $\Delta \Delta \mathrm{P}<0.05$ vs the TRAIL $(2 \mu \mathrm{mol} / \mathrm{L})$ - and Vinco $(80 \mu \mathrm{g} / \mathrm{ml})$-treated group. $N=6$. The images are representative of at least three independent experiments.

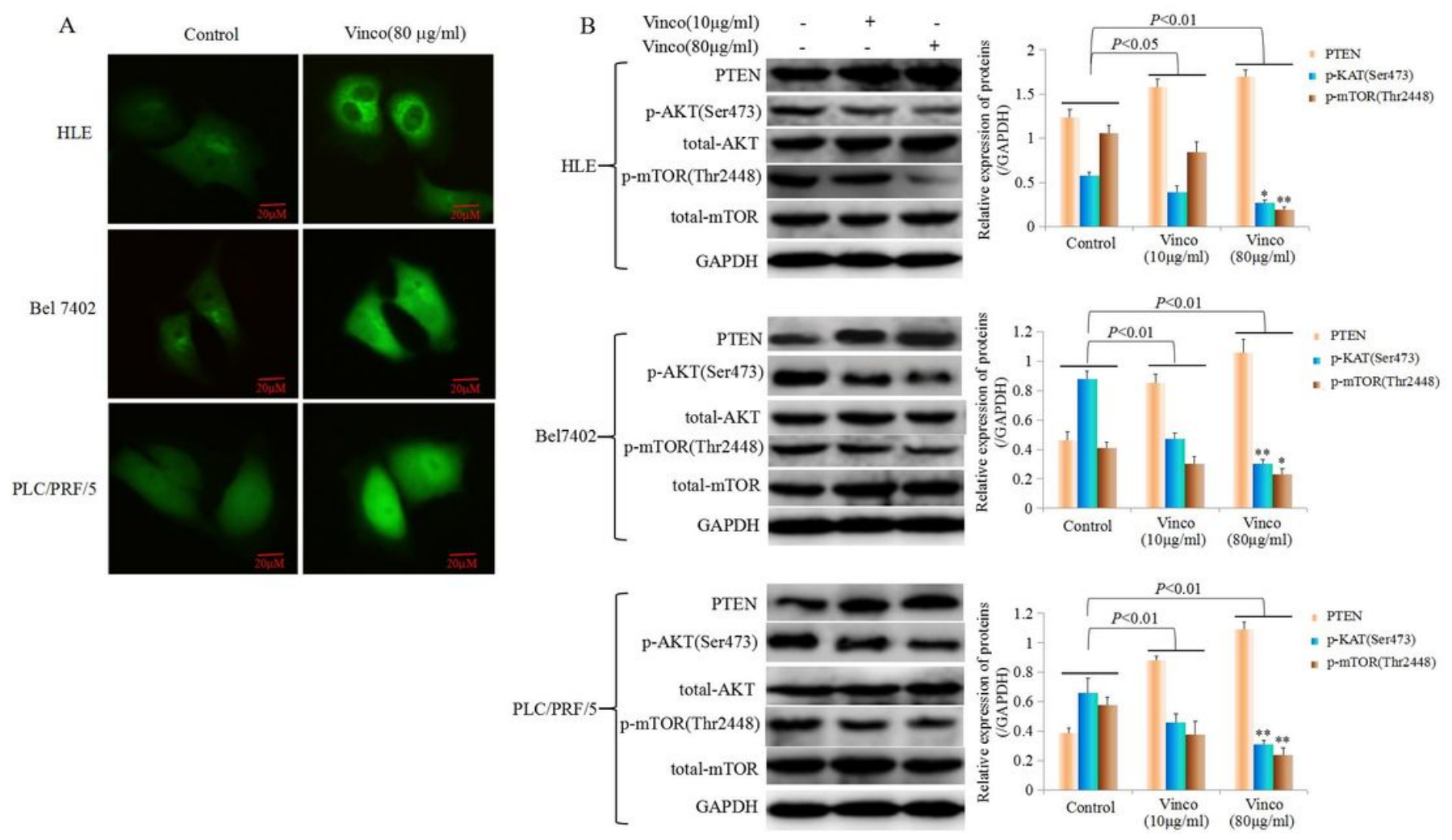

\section{Figure 5}

The influence of Vinco on the expression of PTEN and the proteins which express are regulated by $\mathrm{PI} 3 \mathrm{~K} / \mathrm{AKT}$ signaling pathway in HCC cells. A, HLE, Bel 7402 and PLC/PRF/ 5 cells were treated with Vinco $(80 \mu \mathrm{g} / \mathrm{ml})$ for $48 \mathrm{~h}$, and the expression and localization of PTEN in these cells were observed by laser confocal microscopy. B, HLE, Bel 7402 and PLC/PRF/5 cells were treated with Vinco $(10 \mu \mathrm{g} / \mathrm{ml}$ or 80 $\mu \mathrm{g} / \mathrm{ml}$ ) for $48 \mathrm{~h}$, and the expression of PTEN, pKAT (Ser473), pmTOR (Thr2448) was detected by Western blotting. The bar graphs on the right show relative expressed quantity of these proteins. The images are representative of at least three independent experiments. 
A

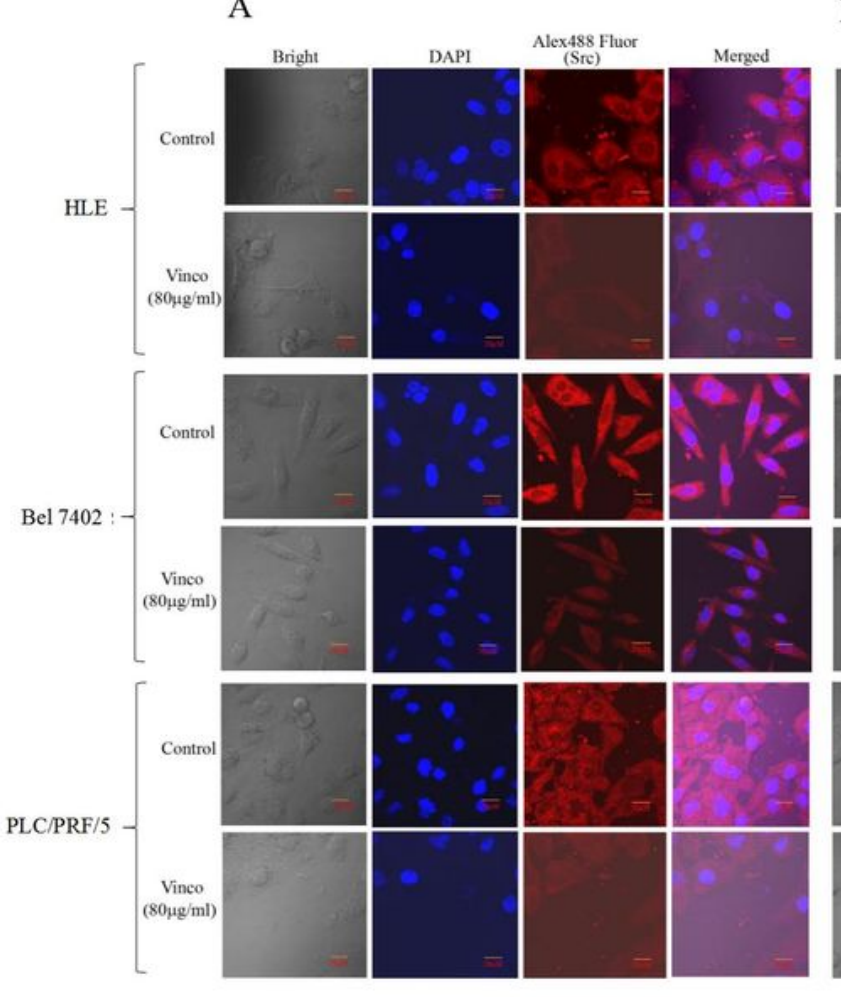

B
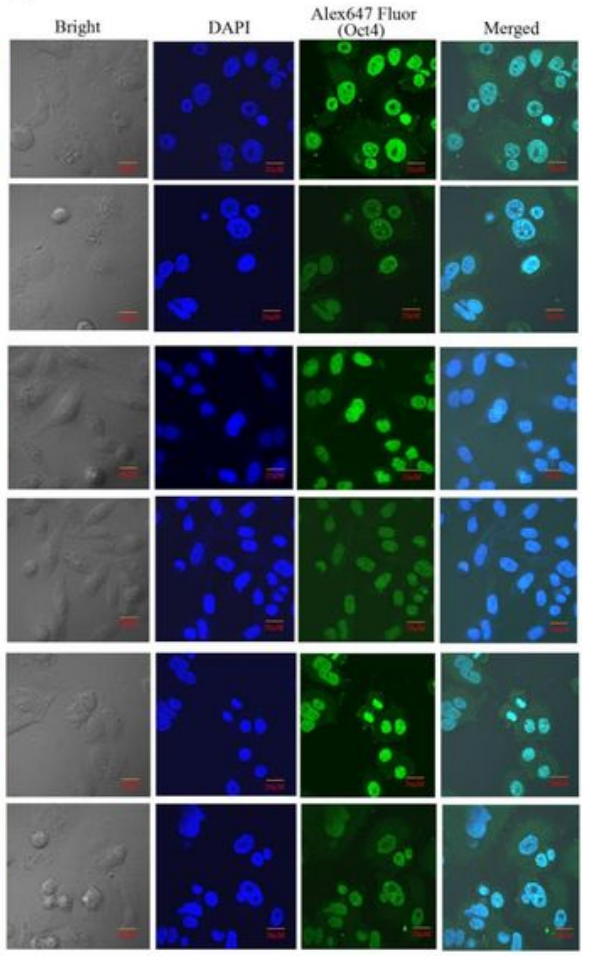
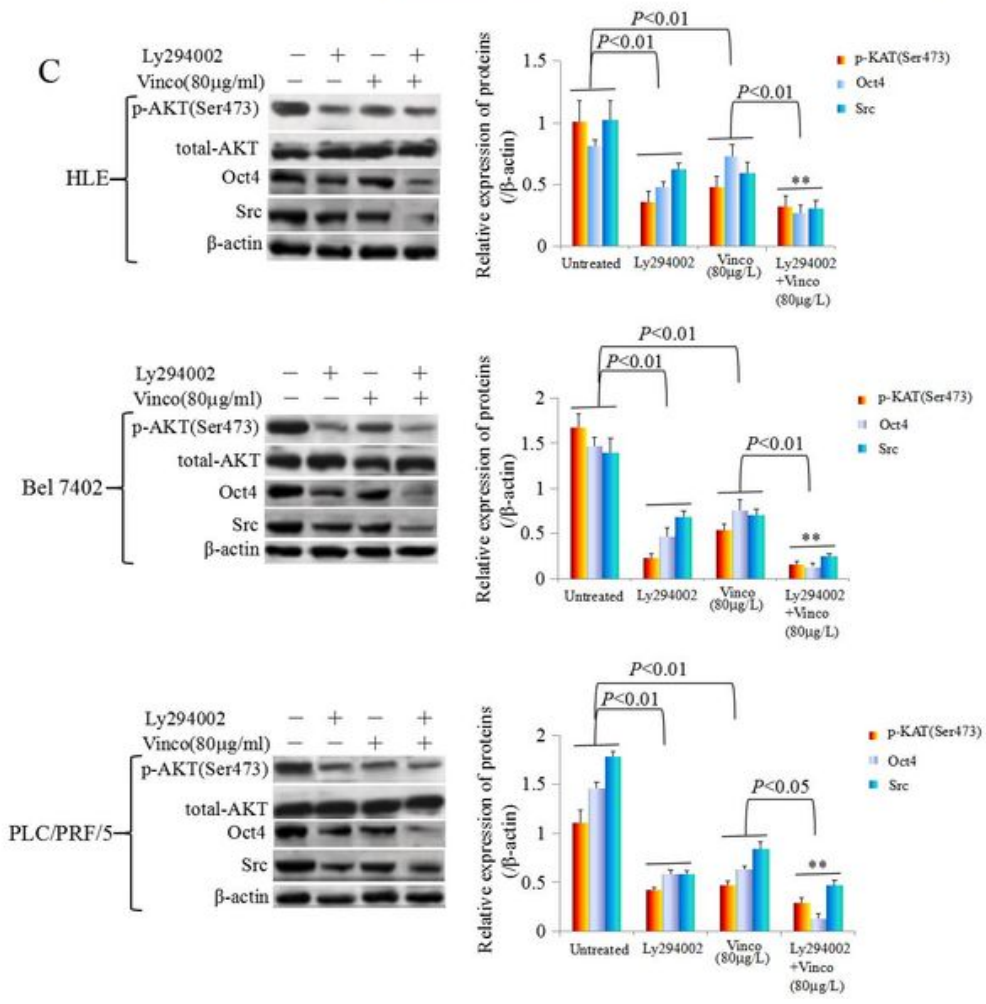

\section{Figure 6}

The influence of Vinco on the expression of the oncogene Src, the reprogramming gene Oct4, and the proteins related to the regulation by PI3K/AKT signaling pathway in HCC cells. HLE, Bel 7402 and PLC/PRF/5 cells were treated with Vinco $(80 \mu \mathrm{g} / \mathrm{ml})$ for $48 \mathrm{~h}$, and the expression and localization of Src (A) and Oct4 (B) in these cells were observed by laser confocal microscopy. C, HLE, Bel 7402 and PLC/PRF/ 5 cells were treated with Vinco $(80 \mu \mathrm{g} / \mathrm{ml})$ or the PI3K inhibitor Ly294002 $(2 \mu \mathrm{mol} / \mathrm{L})$ or 
cotreated with Vinco $(80 \mu \mathrm{g} / \mathrm{ml})$ and Ly294002 $(2 \mu \mathrm{mol} / \mathrm{L})$ for $48 \mathrm{~h}$, and the expression of pAKT (Ser473), $\mathrm{Src}$, and Oct4 was detected by Western blotting. The bar graphs on the right showed relative expressed quantity of these proteins. The images are representative of at least three independent experiments.
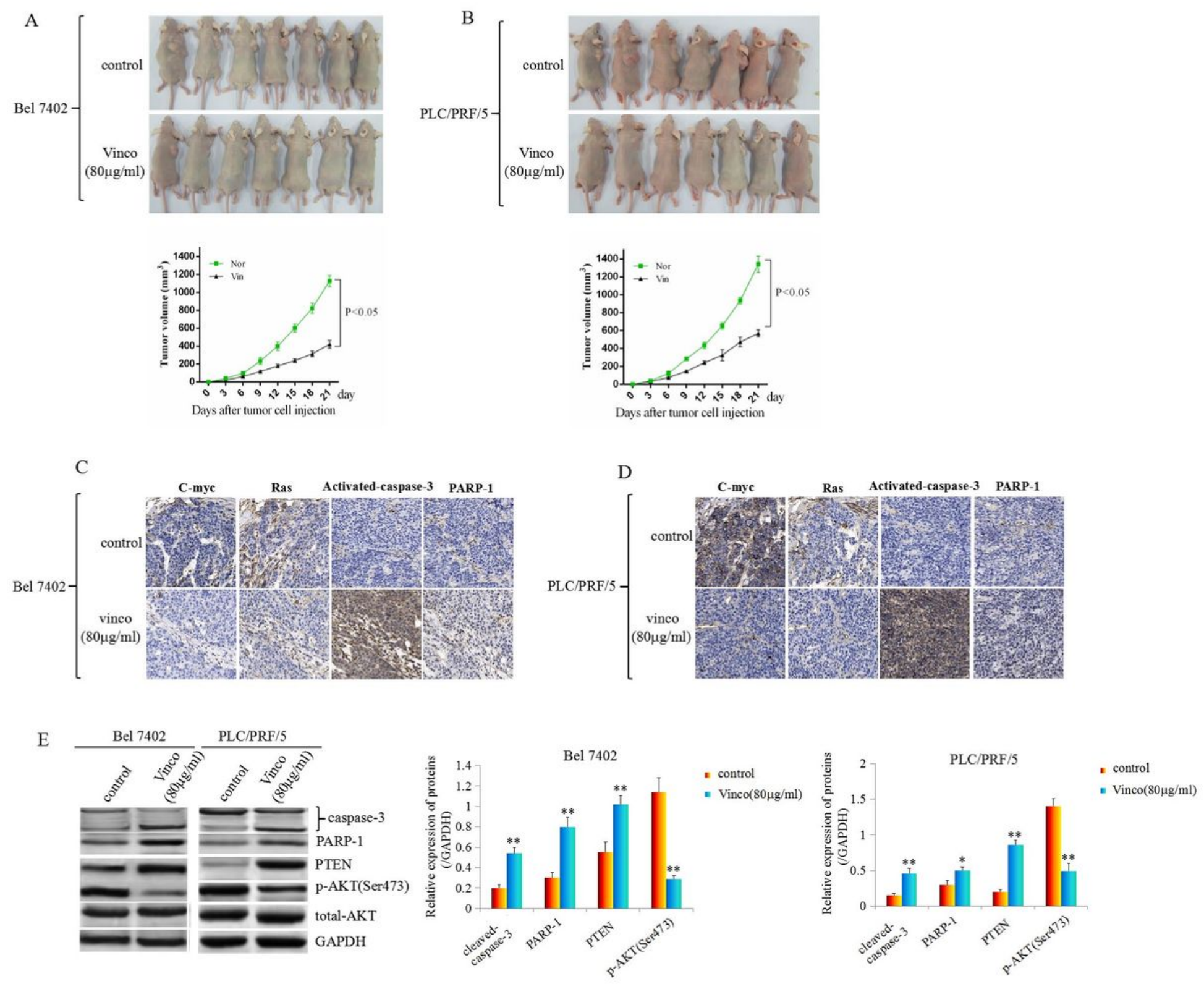

\section{Figure 7}

The effect of Vinco on HCC cell growth, the expression of the growth-related factors PTEN, c-myc, Ras, and pAKT (Ser473), and the activity of caspase-3 in vivo. Bel 7402 (A) and PLC/PRF/5 (B) cells (1×106) in $0.1 \mathrm{~mL}$ of Hank balanced salt solution were subcutaneously injected into the right scapular region of male nude mice $(n=6)$. The mice were intraperitoneally injected with Vinco $(10 \mathrm{mg} / \mathrm{kg} /$ day $)$ every day. Tumor-bearing mice were killed every 3 days after inoculation, the tumors were removed, and the measured length $(\mathrm{L})$, weight $(\mathrm{W})$ of the tumors were measured, and the volume $(\mathrm{V})$ was calculated by formula by the following formula: $V=\pi / 6 \times L \times W 2(\pi=3.14)$. The lower bar graphs show tumor volume. $C$ and D, The expression of c-myc, Ras, cleaved caspase-3 and PARP- 1 in tumorous tissue (from tumorbearing mice on day 21) was detected by immunohistochemistry, and the expression of cleaved caspase- 
3, PARP-1, PTEN and p-AKT (Ser473) in tumorous tissue was detected by Western blotting. The bar graphs on the right show relative expressed quantity of these proteins $(E) .{ }^{*} P<0.05$ and ${ }^{*} \times P<0.01$ vs the untreated group. The images are representative of at least three independent experiments.

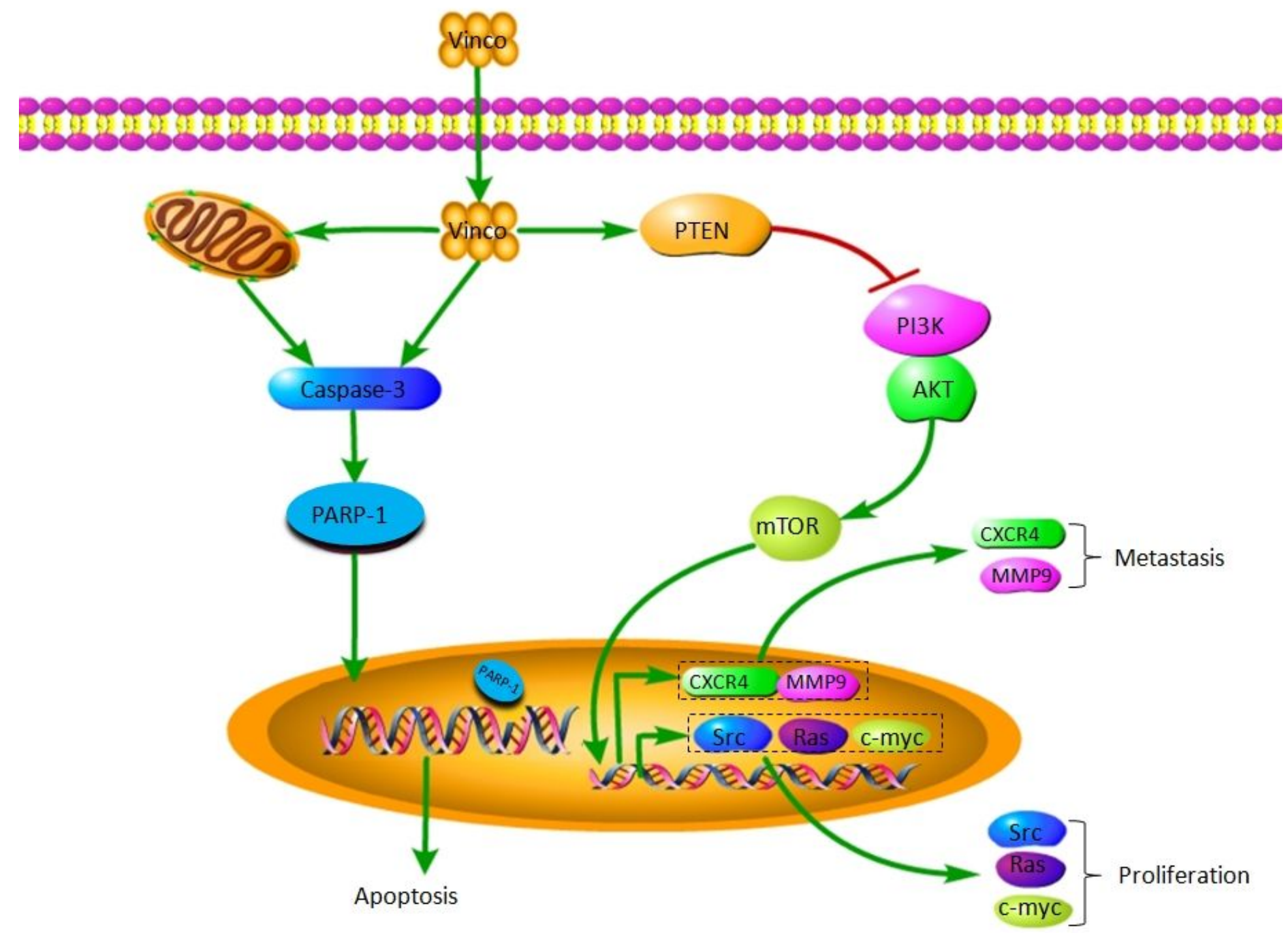

Figure 8

Schematic of the mechanism underlying the role of Vinco in inhibiting the malignancy of HCC cells. 